\title{
Using genetic diversity information to establish core collections of Stylosanthes capitata and Stylosanthes macrocephala
}

Melissa Oliveira Santos-Garcia ${ }^{1 \#}$, Guilherme de Toledo-Silva ${ }^{1 \#}$, Rodrigo Possidonio Sassaki ${ }^{1}$, Thais Helena Ferreira ${ }^{1}$, Rosângela Maria Simeão Resende ${ }^{2}$, Lucimara Chiari ${ }^{2}$, Cláudio Takao Karia ${ }^{3}$, Marcelo Ayres Carvalho ${ }^{3}$, Fábio Gelape Faleiro ${ }^{3}$, Maria Imaculada Zucchi ${ }^{4}$ and Anete Pereira de Souza ${ }^{1,5}$

${ }^{1}$ Centro de Biologia Molecular e Engenharia Genética, Universidade Estadual de Campinas, Campinas, SP, Brazil.

${ }^{2}$ Empresa Brasileira de Pesquisa Agropecuária (Embrapa) - Gado de Corte. Campo Grande, MS, Brazil.

${ }^{3}$ Empresa Brasileira de Pesquisa Agropecuária (Embrapa) - Cerrados. Planaltina, DF, Brazil.

${ }^{4}$ Pólo Centro Sul -Agência Paulista de Tecnologia dos Agronegócios Piracicaba, SP, Brazil.

${ }^{5}$ Departamento de Biologia Vegetal, Instituto de Biologia, Universidade Estadual de Campinas, Campinas, SP, Brazil.

\begin{abstract}
Stylosanthes species are important forage legumes in tropical and subtropical areas. S. macrocephala and $S$. capitata germplasm collections that consist of 134 and 192 accessions, respectively, are maintained at the Brazilian Agricultural Research Corporation Cerrados (Embrapa-Cerrados). Polymorphic microsatellite markers were used to assess genetic diversity and population structure with the aim to assemble a core collection. The mean values of $\mathrm{H}_{0}$ and $\mathrm{H}_{\mathrm{E}}$ for $S$. macrocephala were 0.08 and 0.36 , respectively, whereas the means for $S$. capitata were 0.48 and 0.50 , respectively. Roger's genetic distance varied from 0 to 0.83 for $S$. macrocephala and from 0 to 0.85 for $S$. capitata. Analysis with STRUCTURE software distinguished five groups among the $S$. macrocephala accessions and four groups among those of S. capitata. Nei's genetic diversity was $27 \%$ in S. macrocephala and $11 \%$ in S. capitata. Core collections were assembled for both species. For $S$. macrocephala, all of the allelic diversity was represented by 23 accessions, whereas only 13 accessions were necessary to represent all allelic diversity for $S$. capitata. The data presented herein evidence the population structure present in the Embrapa-Cerrados germplasm collections of $S$. macrocephala and S. capitata, which may be useful for breeding programs and germplasm conservation.
\end{abstract}

Keywords: Stylosanthes, tropical forage, microsatellites, genetic diversity, core collection.

Received: May 26, 2012; Accepted: August 30, 2012.

\section{Introduction}

The genus Stylosanthes Sw. (Fabaceae) consists of approximately 48 species distributed throughout the tropical regions of the Americas, Africa and Asia (Costa and Ferreira, 1984; Mannetje, 1984; Kumar and Sane, 2003). Brazil is considered the major center of Stylosanthes diversity comprising $45 \%$ of all the species within this genus (Ferreira and Costa, 1979; Stace and Cameron, 1984). The central region of Brazil is recognized as having the highest phenotypic variation and endemism for this genus (Costa N, 2006, PhD thesis, Universidade Técnica de Lisboa, Lisboa, Lisbon, Portugal).

Send correspondence to Anete Pereira de Souza. Centro de Biologia Molecular e Engenharia Genética, Universidade Estadual de Campinas, Caixa Postal 6010, 13083-970 Campinas, SP, Brazil. E-mail: anete@unicamp.br.

"These authors contributed equally to this work.
Some Stylosanthes species are used as pasture legumes and thus have economic importance in tropical and subtropical regions (Edye and Cameron, 1984). Some of these species can also be used for soil improvement through nitrogen fixation, regeneration of degraded wastelands, and for promoting water and soil conservation (Chakraborty, 2004).

Stylosanthes macrocephala M.B. Ferr. et Sousa Costa belongs to the section Styposanthes (Mannetje, 1984). It is a diploid species with $2 n=20$. This species occurs on the sandy soils of the Brazilian Cerrado and Caatinga (Costa N, 2006, PhD thesis, Universidade Técnica de Lisboa, Lisbon, Portugal), and several of its ecotypes are tolerant to anthracnose (Colletotrichum gloeosporioides), which is the most important disease that affects this genus (Costa and Ferreira, 1984). The perennial subshrub S. capitata Vog. $(2 n=40)$ occurs in Brazil and Venezuela. It has both prostrate and erect forms. The plant produces a large amount of 
seeds and dry matter, and its inflorescences have a high nutrition value (Williams et al., 1984; Costa N, 2006, PhD thesis, Universidade Técnica de Lisboa, Lisbon, Portugal).

Major collections of important crop plants are held in gene banks around the world. These collections serve as repositories of the biodiversity available for each species and thus are a valuable resource for genes useful to plant breeders. The efficient maintenance and use of germplasm are commonly restricted due to the lack of genetic information and/or by the large numbers of accessions in these collections (Virk et al., 1995). Molecular markers, along with morpho-agronomic data and ecological descriptions of sampling sites have proven to be relevant for evaluating germplasm (Westman and Kresovich, 1997; Zong et al., 2009). The use of molecular markers can also help to select material for establishing a core collection, i.e., a group of accessions from an existing germplasm collection that is chosen to represent the genetic spectrum of the entire collection (Hao et al., 2006). Microsatellites or simple sequence repeats (SSRs) have proven to be among the most suitable markers for such purposes (Huang et al., 2002; Hao et al., 2006; Landjeva et al., 2006; Wang et al., 2006; Ebana et al., 2008; Blair et al., 2009; Cipriani et al., 2010).

In this study, we evaluated the genetic diversity and population structure in accessions of the Embrapa-Cer- rados germplasm collections of $S$. macrocephala and $S$. capitata using polymorphic SSRs. Based on this diversity information, we determined the minimum sample size acceptable for a core collection of each species.

\section{Materials and Methods}

\section{DNA extraction and PCR}

A total of 326 accessions from the Embrapa-Cerrados germplasm collections were used in this study: 134 accessions of S. macrocephala and 192 of S. capitata (Tables 1 and 2). The SSR markers developed by Santos et al. (2009a) (13 SSR S. macrocephala loci) and Santos et al. (2009b) (15 SSR S. capitata loci) were used to assess the genetic diversity of these accessions.

Total DNA was extracted from leaves of three plants from each accession according to the cetyltrimethylammonium bromide method described by Faleiro et al. (2003). PCR amplifications were performed using a PTC200 (MJ Research) thermocycler in a $20-\mu \mathrm{L}$ final reaction volume consisting of $1 \mathrm{X}$ PCR buffer, $1.5 \mathrm{mM} \mathrm{MgCl}$, $0.25 \mathrm{mM}$ of each dNTP (Invitrogen), $0.8 \mu \mathrm{M}$ of each primer, 1U Taq DNA polymerase (Invitrogen) and $20 \mathrm{ng}$ genomic DNA. The amplification protocol consisted of an initial denaturation step at $94{ }^{\circ} \mathrm{C}$ for $1 \mathrm{~min}$, followed by

Table 1 - List of 134 accessions of S. macrocephala from the Embrapa-Cerrados germplasm collection that were analyzed for 13 microsatellite markers. The sample codes, the respective accession numbers and BRA or CIAT numbers in the germplasm collection of Embrapa-Cerrados (CPAC) and the place of origin ${ }^{*}$ are shown.

\begin{tabular}{|c|c|c|c|c|c|c|c|}
\hline Code & CPAC & BRA/CIAT & Place of origin & Code & CPAC & BRA/CIAT & Place of origin \\
\hline 1 & 139 & BRA-003697 & Distrito Federal & 40 & 1341 & BRA-023264 & Bahia \\
\hline 2 & 1030 & CIAT 1942 & Unknow & 41 & 1345 & BRA-022583 & Bahia \\
\hline 3 & 1031 & BRA-007773 & Goiás & 42 & 1346 & BRA-023523 & Bahia \\
\hline 4 & 1032 & BRA-007820 & Goias & 43 & 1347 & BRA-023191 & Bahia \\
\hline 5 & 1033 & BRA-009032 & Bahia & 44 & 1367 & BRA-022284 & Goiás \\
\hline 6 & 1036 & BRA-003008 & Bahia & 45 & 1370 & BRA-023019 & Bahia \\
\hline 7 & 1037 & BRA-008052 & Bahia & 46 & 1373 & BRA-022781 & Bahia \\
\hline 8 & 1039 & CIAT 2079 & Bahia & 47 & 1376 & BRA-022985 & Bahia \\
\hline 9 & 1040 & BRA-008184 & Bahia & 48 & 1378 & BRA-023329 & Bahia \\
\hline 10 & 1043 & BRA-008958 & Bahia & 49 & 1382 & BRA-022586 & Bahia \\
\hline 11 & 1190 & CIAT 2270 & Minas Gerais & 50 & 1383 & BRA-022616 & Bahia \\
\hline 12 & 1191 & CIAT 2271 & Minas Gerais & 51 & 1636 & CIAT 1413 & Unknow \\
\hline 13 & 1192 & BRA-012297 & Minas Gerais & 52 & 1639 & BRA-012866 & Bahia \\
\hline 14 & 1193 & CIAT 2273 & Minas Gerais & 53 & 1640 & BRA-012947 & Bahia \\
\hline 15 & 1194 & CIAT 2274 & Minas Gerais & 54 & 2227 & BRA-013030 & Bahia \\
\hline 16 & 1196 & CIAT 2276 & Minas Gerais & 55 & 2229 & BRA-007226 & Unknow \\
\hline 17 & 1197 & CIAT 2277 & Minas Gerais & 56 & 2230 & BRA-028487 & Goiás \\
\hline 18 & 1198 & CIAT 2278 & Minas Gerais & 57 & 2231 & BRA-28495 & Bahia \\
\hline 19 & 1200 & CIAT 2280 & Minas Gerais & 58 & 2239 & BRA-022828 & Bahia \\
\hline 20 & 1201 & CIAT 2281 & Minas Gerais & 59 & 2254 & BRA-032883 & Minas Gerais \\
\hline 21 & 1202 & CIAT 2282 & Minas Gerais & 60 & 2255 & BRA-032891 & Minas Gerais \\
\hline 22 & 1204 & CIAT 2284 & Minas Gerais & 61 & 2256 & BRA-032905 & Minas Gerais \\
\hline
\end{tabular}


Table 1 (cont.)

\begin{tabular}{|c|c|c|c|c|c|c|c|}
\hline Code & CPAC & BRA/CIAT & Place of origin & Code & CPAC & BRA/CIAT & Place of origin \\
\hline 23 & 1205 & CIAT 2285 & Minas Gerais & 62 & 2257 & BRA-032913 & Minas Gerais \\
\hline 24 & 1206 & CIAT 2286 & Minas Gerais & 63 & 2258 & BRA-032921 & Minas Gerais \\
\hline 25 & 1303 & - & Unknow & 64 & 2259 & BRA-032930 & Minas Gerais \\
\hline 26 & 1304 & - & Unknow & 65 & 2260 & BRA-032948 & Minas Gerais \\
\hline 27 & 1305 & - & Unknow & 66 & 2261 & BRA-032956 & Minas Gerais \\
\hline 28 & 1306 & - & Unknow & 67 & 2262 & BRA-032364 & Minas Gerais \\
\hline 29 & 1307 & BRA-017124 & Distrito Federal & 68 & 2263 & BRA-032972 & Minas Gerais \\
\hline 30 & 1308 & BRA-017639 & Goiás & 69 & 2265 & BRA-032999 & Minas Gerais \\
\hline 31 & 1309 & BRA-017281 & Distrito Federal & 70 & 2266 & BRA-033006 & Minas Gerais \\
\hline 32 & 1310 & BRA-017663 & Distrito Federal & 71 & 2267 & BRA-033014 & Minas Gerais \\
\hline 33 & 1311 & BRA-017442 & Goiás & 72 & 2710 & BRA-028673 & Goiás \\
\hline 34 & 1332 & BRA-023202 & Bahia & 73 & 2711 & BRA-028720 & Bahia \\
\hline 35 & 1333 & BRA-023124 & Bahia & 74 & 2712 & BRA-028789 & Piauí \\
\hline 36 & 1335 & BRA-022837 & Bahia & 75 & 2713 & BRA-028878 & Bahia \\
\hline 37 & 1337 & BRA-023345 & Bahia & 76 & 2714 & BRA-028886 & Bahia \\
\hline 38 & 1339 & BRA-023493 & Bahia & 77 & 2715 & BRA-028908 & Bahia \\
\hline 39 & 1340 & BRA-022829 & Bahia & 78 & 2716 & BRA-028967 & Bahia \\
\hline 79 & 2719 & BRA-029025 & Bahia & 107 & 2709 & - & Unknow \\
\hline 80 & 2720 & BRA-029041 & Bahia & 108 & 2264 & BRA-032981 & Minas Gerais \\
\hline 81 & 2777 & BRA-006245 & Distrito Federal & 109 & 2717 & BRA-028771 & Bahia \\
\hline 82 & 2778 & BRA-011088 & Minas Gerais & 110 & 2790 & BRA-008826 & Bahia \\
\hline 83 & 2782 & BRA-009008 & Bahia & 111 & 2792 & BRA-008257 & Bahia \\
\hline 84 & 2783 & BRA-008061 & Bahia & 112 & 4135 & BRA-036901 & Unknow \\
\hline 85 & 1035 & BRA-008010 & Bahia & 113 & 4137 & BRA-036889 & Unknow \\
\hline 86 & 2795 & BRA-034142 & Minas Gerais & 114 & 1041 & BRA-008222 & Bahia \\
\hline 87 & 4136 & BRA-036871 & Unknow & 115 & 1189 & CIAT 2231 & Rio de Janeiro \\
\hline 88 & 4138 & BRA-036927 & Unknow & 116 & 1045 & BRA-008362 & Bahia \\
\hline 89 & 4139 & BRA-036919 & Unknow & 117 & 1199 & CIAT 2279 & Minas Gerais \\
\hline 90 & 4140 & BRA-036935 & Unknow & 118 & 1187 & BRA-008168 & Bahia \\
\hline 91 & 4166 & BRA-036862 & Unknow & 119 & 1302 & - & Minas Gerais \\
\hline 92 & 4167 & BRA-036820 & Unknow & 120 & 1380 & BRA-022721 & Bahia \\
\hline 93 & 4168 & BRA-036838 & Unknow & 121 & 1641 & BRA-015261 & Goiás \\
\hline 94 & 4200 & BRA-036897 & Unknow & 122 & 1642 & BRA-015253 & Goiás \\
\hline 95 & 4271 & BRA-037541 & Unknow & 123 & 1646 & BRA-050173 & Minas Gerais \\
\hline 96 & 4378 & BRA-036854 & Unknow & 124 & 2232 & BRA-028509 & Bahia \\
\hline 97 & 5184 & BRA-042731 & Minas Gerais & 125 & 2235 & BRA-022516 & Bahia \\
\hline 98 & 5296 & - & Unknow & 126 & 2268 & BRA-033022 & Minas Gerais \\
\hline 99 & 1362 & BRA-23361 & Bahia & 127 & 2721 & BRA-029076 & Bahia \\
\hline 100 & 208 & & Goiás & 128 & 2779 & BRA-007773 & Goiás \\
\hline 101 & 1336 & BRA-024350 & Bahia & 129 & 2780 & BRA-007820 & Goiás \\
\hline 102 & 1363 & BRA-022641 & Bahia & 130 & 2784 & BRA-011126 & Bahia \\
\hline 103 & 1361 & BRA-022411 & Bahia & 131 & 2789 & BRA-006301 & Unknow \\
\hline 104 & 1358 & BRA-022501 & Bahia & 132 & 2794 & BRA-034215 & Minas Gerais \\
\hline 105 & 2251 & BRA-023566 & Minas Gerais & 133 & 4377 & BRA-036846 & Unknow \\
\hline 106 & 2252 & BRA-024252 & Bahia & 134 & 4971 & BRA-041441 & Goiás \\
\hline
\end{tabular}

${ }^{*}$ The geographic sites indicate the Brazilian states in which the plants were collected. 
Table 2 - List of 192 accessions of $S$. capitata from the Embrapa-Cerrados germplasm collection that were analyzed for 13 microsatellite markers. The sample codes , the respective accession numbers and BRA or CIAT numbers in the germplasm collection of Embrapa-Cerrados (CPAC) and the place of origin ${ }^{*}$ are shown.

\begin{tabular}{|c|c|c|c|c|c|c|c|}
\hline Code & $\mathrm{CPAC}$ & BRA/CIAT & Place of origin & Code & CPAC & BRA/CIAT & Place of origin \\
\hline 1 & 515 & BRA-006751 & Mato Grosso do Sul & 40 & 1160 & BRA-001830 & Maranhão \\
\hline 2 & 650 & CIAT 1405 & Mato Grosso do Sul & 41 & 1161 & BRA-001856 & Maranhão \\
\hline 3 & 704 & BRA-007251 & Minas Gerais & 42 & 1162 & BRA-001899 & Piauí \\
\hline 4 & 705 & CIAT 1078 & Bahia & 43 & 1163 & BRA-001902 & Piauí \\
\hline 5 & 706 & BRA-005886 & Bahia & 44 & 1164 & BRA-001911 & Piauí \\
\hline 6 & 707 & BRA-001791 & Maranhão & 45 & 1165 & BRA-000400 & Piauí \\
\hline 7 & 901 & CIAT 2249 & Minas Gerais & 46 & 1166 & BRA-001929 & Piauí \\
\hline 8 & 906 & CIAT 1419 & Goiás & 47 & 1167 & BRA-001937 & Piauí \\
\hline 9 & 908 & CIAT 1440 & Ceará & 48 & 1168 & CIAT 2220 & Bahia \\
\hline 10 & 909 & CIAT 1441 & São Paulo & 49 & 1169 & BRA-006190 & Goiás \\
\hline 11 & 913 & BRA-006742 & Mato Grosso & 50 & 1170 & BRA-009181 & Pernambuco \\
\hline 12 & 915 & CIAT 1892 & Venezuela & 51 & 1171 & BRA-007544 & Ceará \\
\hline 13 & 916 & CIAT 1899 & Venezuela & 52 & 1172 & BRA-007522 & Ceará \\
\hline 14 & 918 & CIAT 1924 & Venezuela & 53 & 1174 & BRA-007595 & Ceará \\
\hline 15 & 922 & BRA-007625 & Distrito Federal & 54 & 1177 & CIAT 2259 & Minas Gerais \\
\hline 16 & 924 & BRA-007749 & Goiás & 55 & 1178 & CIAT 2260 & Minas Gerais \\
\hline 17 & 925 & BRA-007871 & Goiás & 56 & 1182 & CIAT 2265 & Minas Gerais \\
\hline 18 & 926 & BRA-007846 & Goiás & 57 & 1183 & CIAT 2266 & Minas Gerais \\
\hline 19 & 928 & BRA-007803 & Goiás & 58 & 1185 & CIAT 2268 & Minas Gerais \\
\hline 20 & 929 & BRA-007838 & Goiás & 59 & 1186 & CIAT 2269 & Minas Gerais \\
\hline 21 & 931 & BRA-009059 & Bahia & 60 & 1278 & BRA-017787 & Minas Gerais \\
\hline 22 & 934 & BRA-007960 & Bahia & 61 & 1279 & BRA-017795 & Minas Gerais \\
\hline 23 & 935 & BRA-007994 & Bahia & 62 & 1281 & - & Minas Gerais \\
\hline 24 & 936 & BRA-008001 & Bahia & 63 & 1282 & BRA-017881 & Goiás \\
\hline 25 & 938 & BRA-008087 & Bahia & 64 & 1283 & BRA-017043 & Goiás \\
\hline 26 & 939 & BRA-008176 & Bahia & 65 & 1284 & BRA-017094 & Goiás \\
\hline 27 & 940 & BRA-008231 & Bahia & 66 & 1285 & BRA-016659 & Goiás \\
\hline 28 & 943 & BRA-008907 & Bahia & 67 & 1286 & BRA-016675 & Goiás \\
\hline 29 & 944 & BRA-008869 & Bahia & 68 & 1287 & BRA-016713 & Goiás \\
\hline 30 & 945 & BRA-008818 & Bahia & 69 & 1288 & BRA-016519 & Goiás \\
\hline 31 & 947 & BRA-008401 & Bahia & 70 & 1289 & BRA-016586 & Goiás \\
\hline 32 & 949 & BRA-008532 & Bahia & 71 & 1290 & BRA-016403 & Bahia \\
\hline 33 & 950 & BRA-008583 & Bahia & 72 & 1291 & BRA-016186 & Goiás \\
\hline 34 & 951 & BRA-008621 & Bahia & 73 & 1292 & BRA-016268 & Goiás \\
\hline 35 & 952 & BRA-008681 & Bahia & 74 & 1293 & BRA-016144 & Goiás \\
\hline 36 & 953 & BRA-008761 & Bahia & 75 & 1294 & BRA-015962 & Goiás \\
\hline 37 & 956 & CIAT 2218 & Bahia & 76 & 1295 & BRA-022136 & Goiás \\
\hline 38 & 957 & CIAT 2219 & Bahia & 77 & 1296 & BRA-016039 & Goiás \\
\hline 39 & 959 & CIAT 2228 & São Paulo & 78 & 1297 & BRA-016098 & Goiás \\
\hline 79 & 1298 & BRA-017507 & Goiás & 121 & 2226 & BRA-032859 & Minas Gerais \\
\hline 80 & 1299 & BRA-017566 & Goiás & 122 & 2681 & BRA-029084 & Bahia \\
\hline 81 & 1300 & BRA-017396 & Goiás & 123 & 2682 & BRA-029068 & Bahia \\
\hline 82 & 1328 & BRA-013517 & Goiás & 124 & 2685 & BRA-028860 & Bahia \\
\hline 83 & 1350 & BRA-011749 & Maranhão & 125 & 2686 & BRA-028851 & Piauí \\
\hline 84 & 1357 & BRA-13371 & Maranhão & 126 & 2687 & BRA-028843 & Piauí \\
\hline 85 & 1384 & BRA-022314 & Maranhão & 127 & 2689 & BRA-028827 & Piauí \\
\hline 86 & 1386 & BRA-023485 & Goiás & 128 & 2691 & BRA-028738 & Bahia \\
\hline 87 & 1387 & BRA-024317 & Bahia & 129 & 2692 & BRA-028746 & Bahia \\
\hline
\end{tabular}


Table 2 (cont.)

\begin{tabular}{|c|c|c|c|c|c|c|c|}
\hline Code & CPAC & BRA/CIAT & Place of origin & Code & CPAC & BRA/CIAT & Place of origin \\
\hline 88 & 1388 & BRA-023299 & Bahia & 130 & 2694 & BRA-028681 & Goiás \\
\hline 89 & 1389 & BRA-22446 & Bahia & 131 & 2695 & BRA-028762 & Piauí \\
\hline 90 & 1392 & BRA-022772 & Bahia & 132 & 2696 & BRA-028657 & Goiás \\
\hline 91 & 1394 & BRA-024261 & Bahia & 133 & 2835 & BRA-014346 & Ceará \\
\hline 92 & 1395 & BRA-022373 & Bahia & 134 & 2837 & BRA-014362 & Ceará \\
\hline 93 & 1588 & BRA-012874 & Bahia & 135 & 2839 & BRA-014443 & Piauí \\
\hline 94 & 1590 & BRA-012955 & Bahia & 136 & 2840 & BRA-035190 & Piauí \\
\hline 95 & 1591 & BRA-003671 & Bolivia & 137 & 2841 & BRA-014397 & Piauí \\
\hline 96 & 1592 & BRA-013021 & Sergipe & 138 & 2842 & BRA-001848 & Maranhão \\
\hline 97 & 1594 & BRA-013935 & Sergipe & 139 & 2844 & BRA-031160 & Mato Grosso \\
\hline 98 & 1596 & BRA-014036 & Bahia & 140 & 4123 & BRA-036137 & Ceará \\
\hline 99 & 1597 & BRA-014117 & Bahia & 141 & 2821 & BRA-035173 & Venezuela \\
\hline 100 & 1600 & BRA-015202 & Goiás & 142 & 2822 & BRA-012840 & Bahia \\
\hline 101 & 1598 & BRA-015229 & Goiás & 143 & 2823 & BRA-001881 & Maranhão \\
\hline 102 & 1601 & BRA-015199 & Goiás & 144 & 2826 & BRA-014401 & Piauí \\
\hline 103 & 1608 & CIAT 2829 & Venezuela & 145 & 2828 & BRA-035181 & Mato Grosso \\
\hline 104 & 1609 & BRA-011720 & Maranhão & 146 & 2829 & BRA-014532 & Maranhão \\
\hline 105 & 1611 & BRA-050173 & Minas Gerais & 147 & 2830 & BRA-014508 & Maranhão \\
\hline 106 & 1612 & BRA-033219 & Distrito Federal & 148 & 2831 & BRA-014281 & Ceará \\
\hline 107 & 1616 & BRA-028177 & Goiás & 149 & 2833 & BRA-035157 & Distrito Federal \\
\hline 108 & 1617 & CIAT 2946 & Goiás & 150 & 2834 & BRA-000850 & Piauí \\
\hline 109 & 1618 & BRA-040738 & Colômbia & 151 & 2798 & BRA-014311 & Ceará \\
\hline 110 & 2207 & BRA-027961 & Bahia & 152 & 2807 & BRA-005924 & Minas Gerais \\
\hline 111 & 2208 & BRA-028002 & Goiás & 153 & 2809 & BRA-005908 & Venezuela \\
\hline 112 & 2209 & BRA-028053 & Venezuela & 154 & 2811 & BRA-021491 & Distrito Federal \\
\hline 113 & 2211 & BRA-028185 & Minas Gerais & 155 & 2817 & BRA-005975 & Venezuela \\
\hline 114 & 2212 & BRA-014265 & Ceará & 156 & 2813 & BRA-001864 & Maranhão \\
\hline 115 & 2213 & BRA-014320 & Ceará & 157 & 2819 & BRA-013455 & Paraíba \\
\hline 116 & 2214 & BRA-014427 & Piauí & 158 & 4125 & BRA-036081 & Ceará \\
\hline 117 & 2215 & BRA-007579 & Ceará & 159 & 4129 & BRA-036153 & Piauí \\
\hline 118 & 2216 & BRA-008240 & Bahia & 160 & 4130 & BRA-036161 & Maranhão \\
\hline 119 & 2217 & BRA-028258 & Bahia & 161 & 4131 & BRA-036188 & Maranhão \\
\hline 120 & 2224 & BRA-032832 & Minas Gerais & 162 & 4155 & BRA-035971 & Bahia \\
\hline 163 & 4156 & BRA-035963 & Bahia & 178 & 4354 & BRA-036129 & Ceará \\
\hline 164 & 4158 & BRA-035955 & Goiás & 179 & 4355 & BRA-036145 & Ceará \\
\hline 165 & 4159 & BRA-036048 & Bahia & 180 & 4356 & BRA-036170 & Maranhão \\
\hline 166 & 4341 & BRA-035939 & Distrito Federal & 181 & 4357 & BRA-036196 & Maranhão \\
\hline 167 & 4343 & BRA-035980 & Bahia & 182 & 4359 & BRA-036218 & Goiás \\
\hline 168 & 4344 & BRA-035998 & Bahia & 183 & 4360 & BRA-036226 & Goiás \\
\hline 169 & 4345 & BRA-036005 & Bahia & 184 & 4362 & BRA- 037583 & Goiás \\
\hline 170 & 4346 & BRA-036013 & Bahia & 185 & 4363 & BRA-037605 & Goiás \\
\hline 171 & 4347 & BRA-036021 & Bahia & 186 & 4364 & BRA-037770 & São Paulo \\
\hline 172 & 4348 & BRA-036030 & Bahia & 187 & 4973 & BRA-041467 & Minas Gerais \\
\hline 173 & 4349 & BRA-036056 & Ceará & 188 & 4974 & BRA-041475 & Minas Gerais \\
\hline 174 & 4350 & BRA-036064 & Ceará & 189 & 4977 & BRA-041505 & Minas Gerais \\
\hline 175 & 4351 & BRA-036072 & Ceará & 190 & 4981 & BRA-041543 & Bahia \\
\hline 176 & 4352 & BRA-036099 & Ceará & 191 & 4982 & BRA-041556 & Bahia \\
\hline 177 & 4353 & BRA-036111 & Ceará & 192 & 4984 & BRA-041572 & Bahia \\
\hline
\end{tabular}

*The geographic sites indicate the country or Brazilian states in which the plants were collected. 
30 cycles of $94{ }^{\circ} \mathrm{C}$ for $1 \mathrm{~min}, 60^{\circ} \mathrm{C}$ for $1 \mathrm{~min}$ and at $72{ }^{\circ} \mathrm{C}$ for $1 \mathrm{~min}$, with a final extension step at $72^{\circ} \mathrm{C}$ for $5 \mathrm{~min}$. PCR-amplified DNA fragments were separated by electrophoresis on $6 \%$ denaturing polyacrylamide gels at $75 \mathrm{~W}$ for approximately $2 \mathrm{~h}$ and then stained with silver nitrate according to Creste et al. (2001). Allele scoring was done by comparison to a 10-bp DNA ladder (10-330 bp range) (Invitrogen).

\section{Data analysis}

Allele frequencies, observed and expected heterozygosities $\left(\mathrm{H}_{\mathrm{O}}\right.$ and $\left.\mathrm{H}_{\mathrm{E}}\right)$ and Roger's genetic distance modified by Wright (1978) were calculated using the Tools for Population Genetic Analysis (TFPGA) software (Miller, 1997). Population structure was inferred using STRUCTURE 2.0 software (Pritchard et al., 2000), and the accessions were assigned to groups based on their genotypes. STRUCTURE uses model-based clustering in which a Bayesian approach identifies clusters based on their fit to Hardy-Weinberg and linkage equilibria.

The optimum number of populations $(\mathrm{K})$ was selected after ten independent runs with a burn-in period of 300,000 and 400,000 replications using a model that does not allow for admixture or correlated allele frequencies. The procedure described by Evanno et al. (2005) was used to estimate the most probable number of distinct genetic groups $(\mathrm{K})$ in each germplasm collection. Nei's $\mathrm{G}_{\mathrm{ST}}$ among the groups defined by the STRUCTURE analysis was calculated using the software FSTAT (Goudet, 2001).

Genetic relationships among the accessions based on the genotypic data and Roger's genetic distance were estimated using a Neighbor-Joining method in DARwin 5.0 software (Perrier and Jacquemoud-Collet, 2006).

Finally, by using the software COREFINDER ( $\mathrm{Ci}$ priani et al., 2010) we assembled a core collection that should represent $100 \%$ of the genetic diversity present within the entire collection.

\section{Results}

We used SSR markers developed for S. macrocephala and S. capitata to genotype all of the accessions in germplasm collections of both species. In S. macrocephala, 61 alleles were identified at 13 microsatellite loci, and 51 alleles were identified at 15 loci in S. capitata. In $S$. macrocephala the range was 2 to 11 alleles per locus ( 4.7 average) (Table 3), with $\mathrm{H}_{\mathrm{E}}$ values ranging from 0.02 to 0.85 ( 0.36 on average) and $\mathrm{H}_{\mathrm{O}}$ values varying from 0.01 to 0.17 ( 0.08 on average), thus representing a low level of genetic diversity. With regard to the $S$. capitata descriptive data, the numbers of alleles ranged from 2 to 9 for all of the loci analyzed (3.4 on average) (Table 4); the $\mathrm{H}_{\mathrm{E}}$ values ranged from 0.27 to 0.74 ( 0.50 on average), and the $\mathrm{H}_{\mathrm{O}}$ values rom 0.04 to 0.87 ( 0.48 on average). Roger's genetic distance values among the $S$. macrocephala accessions ranged
Table 3 - The 13 microsatellite loci used for the analysis of the Embrapa germplasm collection of $S$. macrocephala. The number of alleles $(\mathrm{N})$ and observed and expected heterozygosities $\left(\mathrm{H}_{\mathrm{O}}\right.$ and $\mathrm{H}_{\mathrm{E}}$, respectively) are indicated for each locus.

\begin{tabular}{lccc}
\hline Locus & $\mathrm{N}$ & $\mathrm{H}_{\mathrm{O}}$ & $\mathrm{H}_{\mathrm{E}}$ \\
\hline SM02 A5 & 2 & 0.01 & 0.07 \\
SM02 A10 & 3 & 0.01 & 0.02 \\
SM01 D3 & 2 & 0.02 & 0.04 \\
SM02 A2 & 11 & 0.19 & 0.85 \\
SM01 B11 & 7 & 0.05 & 0.70 \\
SM02 C9 & 3 & 0.04 & 0.07 \\
SM02 G2 & 2 & 0.07 & 0.26 \\
SM02 G5 & 8 & 0.14 & 0.80 \\
SM01 B5 & 2 & 0.02 & 0.04 \\
SM01 B6 & 3 & 0.07 & 0.36 \\
SM02 A8 & 3 & 0.16 & 0.54 \\
SM02 A9 & 4 & 0.08 & 0.14 \\
SM02 G3B & 11 & 0.17 & 0.75 \\
Average & 4.7 & 0.08 & 0.36 \\
\hline
\end{tabular}

Table 4 - The 15 microsatellite loci used for the analysis of the Embrapa germplasm collection of $S$. capitata. The number of alleles $(\mathrm{N})$ and observed and expected heterozygosities $\left(\mathrm{H}_{\mathrm{O}}\right.$ and $\mathrm{H}_{\mathrm{E}}$, respectively) are indicated for each locus.

\begin{tabular}{lccc}
\hline Locus & $\mathrm{N}$ & $\mathrm{H}_{\mathrm{O}}$ & $\mathrm{H}_{\mathrm{E}}$ \\
\hline SC 01 TF6A & 3 & 0.52 & 0.40 \\
SC 01 C7B & 5 & 0.87 & 0.59 \\
SC 01 E10A & 3 & 0.68 & 0.45 \\
SC 01 E4 & 3 & 0.52 & 0.40 \\
SC 01 E11 & 3 & 0.64 & 0.44 \\
SC 01 A5 & 8 & 0.40 & 0.66 \\
SC 01 E10B & 3 & 0.72 & 0.46 \\
SC 01 TG9 & 3 & 0.48 & 0.44 \\
SC 01 B3 & 3 & 0.41 & 0.41 \\
SC 01 TF11A & 3 & 0.45 & 0.46 \\
SC 01 TG12A & 5 & 0.39 & 0.61 \\
SC 01 A2A & 3 & 0.28 & 0.27 \\
SC 02 E12 & 9 & 0.41 & 0.71 \\
SC 01 H5 & 5 & 0.04 & 0.54 \\
SC 01 H6A & 6 & 0.45 & 0.71 \\
Average & 4.3 & 0.48 & 0.50 \\
\hline
\end{tabular}

from 0 to 0.83 , with an average of 0.54 , whereas these values ranged from 0 to 0.85 ( 0.50 average) for $S$. capitata.

The method of Evanno et al. (2005) was used to define the maximal $\Delta \mathrm{K}$, which was at $\mathrm{K}=5$ in the $S$. macrocephala germplasm collection, based on the STRUCTURE analysis (Figure 1). Cluster analysis revealed that 75 of the accessions (57\%) were assigned to a single group with 

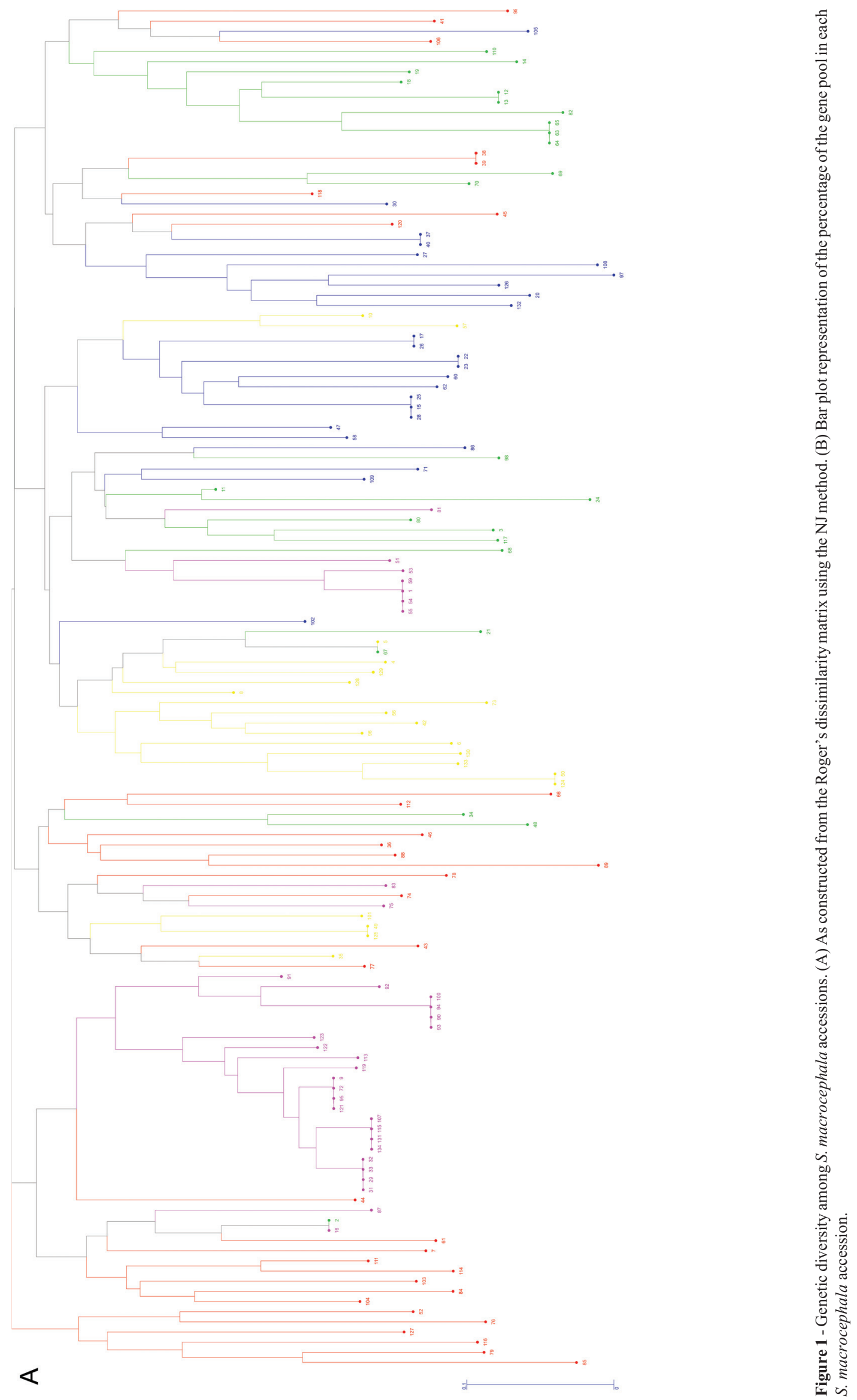

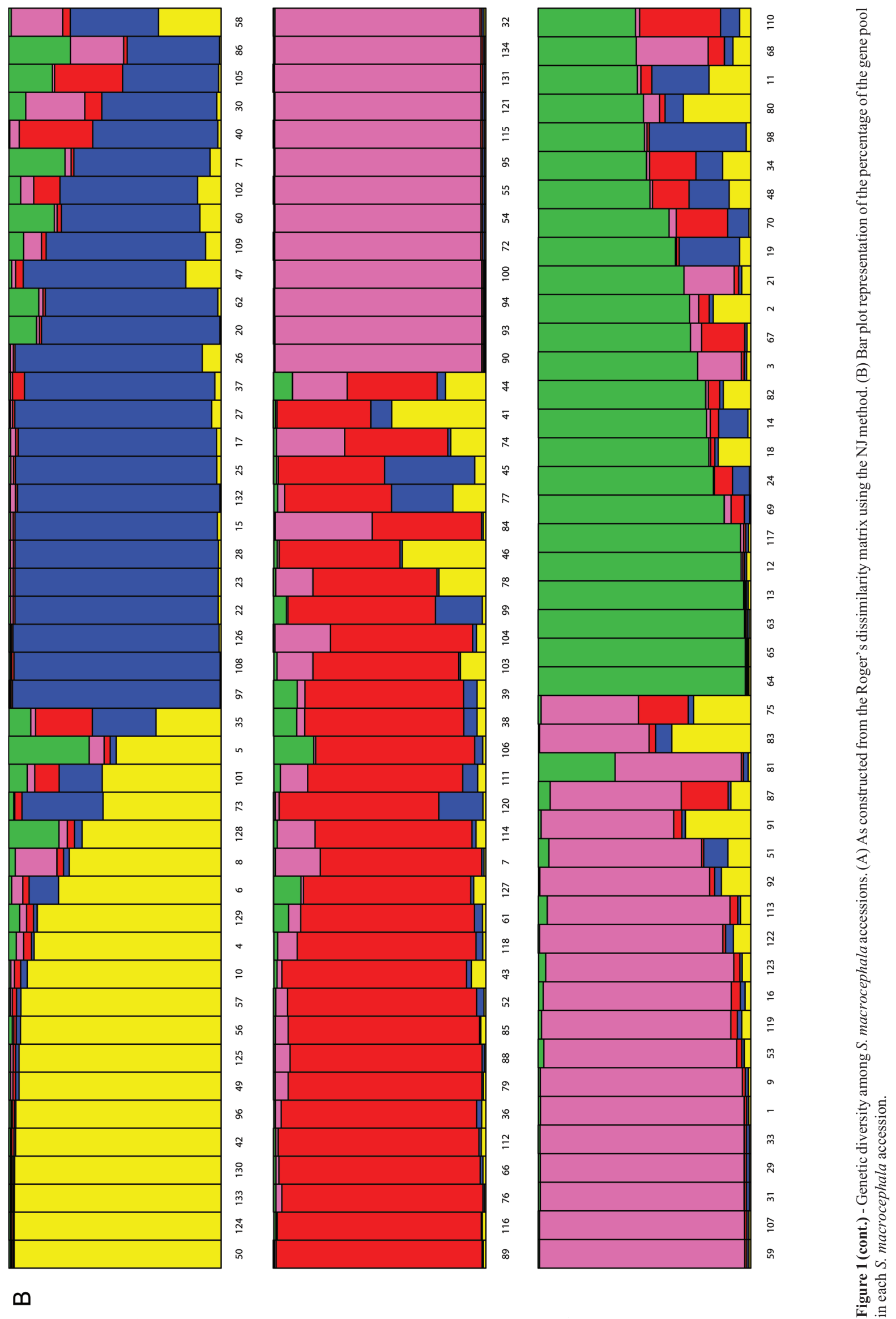
more than $80 \%$ probability, whereas the other 59 accessions represented a mixture of different groups. Group D comprised the largest number of non-mixed accessions, with $79 \%$ of the individuals in this cluster showing more than $80 \%$ probability of membership. In contrast, most accessions in groups $\mathrm{C}$ and $\mathrm{E}$ had less than $80 \%$ probability of membership (59\% and $62 \%$, respectively). The descriptive data calculated for the individual clusters revealed that $\mathrm{H}_{\mathrm{O}}$ ranged from 0.03 in group $\mathrm{D}$ to 0.14 in group $\mathrm{C}$, and that $\mathrm{H}_{\mathrm{E}}$ values varied from 0.14 in group $\mathrm{D}$ to 0.38 in group $\mathrm{C}$.

The STRUCTURE procedure clustered the $S$. capitata germplasm accessions into four groups (Figure 2), wherein 131 accessions $(68 \%)$ were assigned to a single group with more than $80 \%$ probability of membership, and the remaining 61 accessions were so to different groups. Group D contained the largest number of accessions assigned with more than $80 \%$ membership probability $(97 \%)$, whereas group A contained the highest percentage of mixed accessions $(61 \%) . \mathrm{H}_{\mathrm{O}}$ values ranged from 0.40 in group $\mathrm{A}$ to 0.56 in group $\mathrm{C}$, and $\mathrm{H}_{\mathrm{E}}$ values varied from 0.40 in group $\mathrm{A}$ to 0.49 in groups $\mathrm{C}$ and $\mathrm{D}$. The Nei's genetic diversity among the groups $\left(\mathrm{G}_{\mathrm{ST}}\right)$ was calculated to infer the proportion of genetic diversity due to differences among the groups clustered by STRUCTURE in both species. $\mathrm{G}_{\mathrm{ST}}$ values were $27 \%$ and $11 \%$ for $S$. macrocephala and $S$. capitata, respectively.

We used DARwin software to arrive at a Neighbor-Joining (NJ) tree derived from the Roger's genetic distance results (Figures 1 and 2). In this analysis, the clusters formed by STRUCTURE with high levels of mixed accessions (less than $80 \%$ probability) became dispersed along the NJ tree.

We assembled representative core collections for both species (Figure 3), aiming to obtain $100 \%$ of the genetic diversity observed in this study. This goal was accomplished with 23 accessions of S. macrocephala and 13 accessions of $S$. capitata. The alleles identified in this study were fully represented in these core collections.

\section{Discussion}

The SSR markers analyzed in this work were suitable for evaluating the genetic information in the accessions of S. macrocephala and S. capitata. Santos et al. (2009c) observed the same range of alleles per locus (2 to 11) in 20 accessions of this same $S$. macrocephala germplasm collection, but with a smaller average of four alleles per locus. In S. capitata, another study observed a range of alleles per locus that varied from 2 to 7 alleles per locus and averaged 3.3 in 20 accessions of the same germplasm collection analyzed using eight microsatellites (Santos et al., 2009b). In S. guianensis (Aubl.) Sw., the analysis of 20 loci in 20 accessions revealed allele numbers between two and seven, with an average of four (Santos et al., 2009c). However, when the number of S. guianensis accessions was increased to 150 , the number of alleles per locus was equal to the vari-

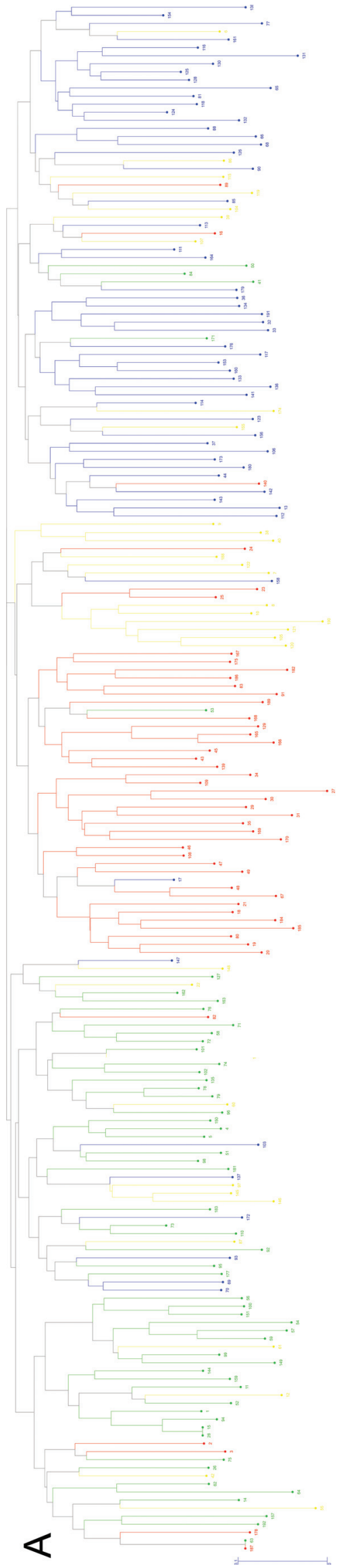



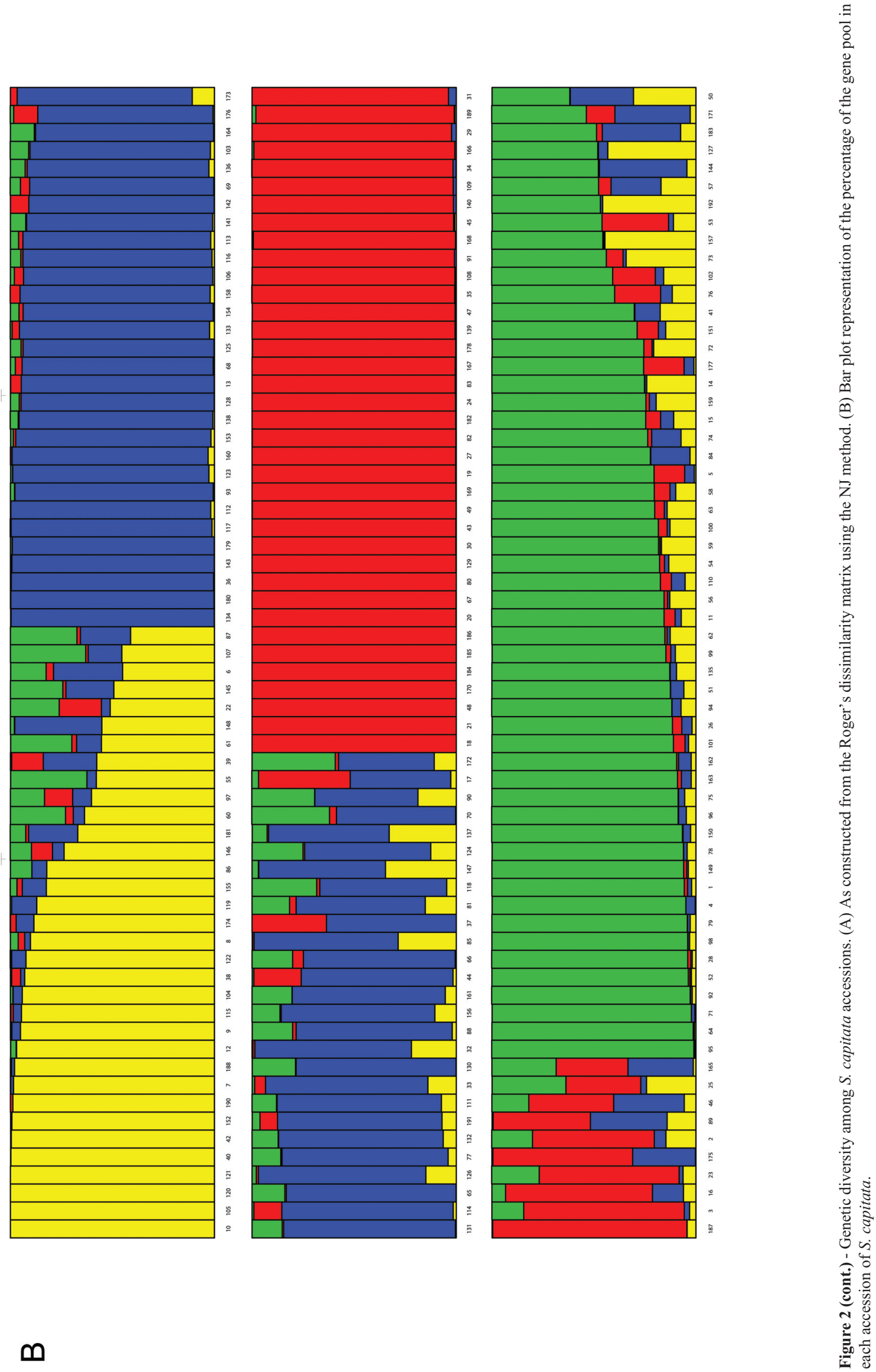


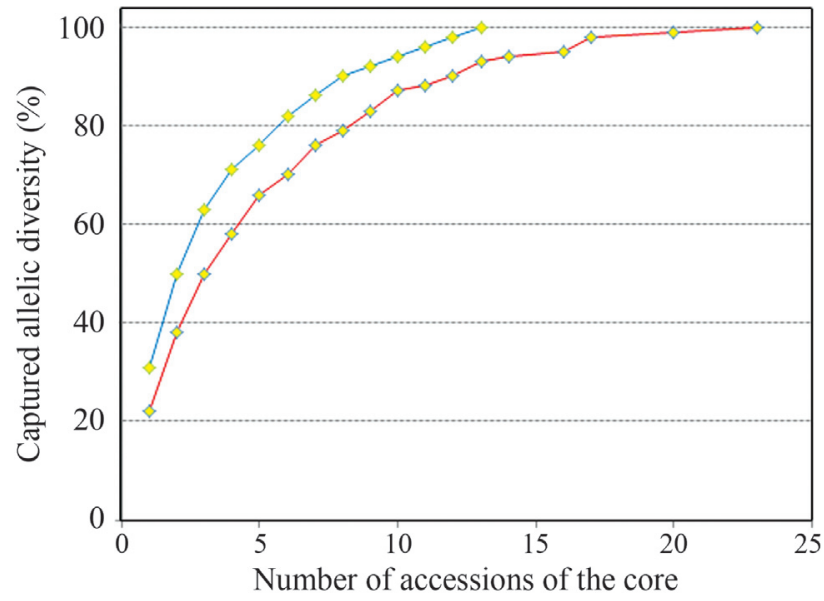

Figure 3 - Genetic diversity as a function of the number of accessions included in the S. macrocephala (red) and S. capitata (blue) core collections.

ation (2 to 11) and average (4.7) observed here for $S$. macrocephala (Santos-Garcia MO, 2009, PhD thesis, Universidade Estadual de Campinas, Campinas, Brazil). The allele sizes of $S$. macrocephala were consistent with the expected sizes reported in Santos et al. (2009a,c), with the exception of a few differences that occurred when higher numbers of alleles were observed for the same loci. The $S$. capitata accessions exhibited high levels of heterozygosity. Vander Stappen et al. (2002) showed that allotetraploid Stylosanthes species have high levels of fixed heterozygosity, which may explain the observed heterozygosity rates identified in the germplasm collection described for this study. As we used bulk samples, the observed heterozygosity could be explained by outcrossing and the inclusion of heterozygous individuals, or by heterogeneity in the GenBank accessions (Zhang et al., 2008).

The genetic distances denoted in this study were higher than those previously reported for other species of the genus Stylosanthes. One possible explanation is that a larger number of accessions were analyzed here than in other studies. Furthermore, the types of molecular markers used in the previous studies were generally less polymorphic than our SSR markers. Barros et al. (2005) studied a subset of 86 accessions from the same $S$. macrocephala germplasm collection studied here using 15 RAPD primers and reported genetic distances ranging from 0.02 to 0.42 . Hence, the microsatellite markers used herein revealed more genetic variation than the RAPD markers, similar to what has been shown in studies on other species (Powell et al., 1996; Sun et al., 1999; Laborda et al., 2005). When evaluated using RAPD markers, the genetic dissimilarity in S. scabra J. Vogel was 0.06 among the accessions from Brazil, Colombia and Venezuela, and for S. guianensis, it averaged 0.26 among 31 accessions (Kazan et al., 1993). The genetic distances among $42 \mathrm{~S}$. guianensis accessions varied from 0.05 to 0.69 when measured using AFLP analysis (Chang-Shun et al., 2004), and a recent analysis of 150
S. guianensis accessions using 20 microsatellite markers also resulted in high genetic distance values (Santos-Garcia et al., 2012).

The population structure in the accessions of $S$. macrocephala and $S$. capitata was examined using STRUCTURE 2.0, which uses a Bayesian clustering approach to probabilistically assign individuals to populations based on their genotypes. The analysis of population structure using the model-based approach of Pritchard et al. (2000) provided support for the existence of genetic structure in these germplasm collections. Accordingly, five groups were formed among the $S$. macrocephala accessions, and four groups were formed among the $S$. capitata accessions.

The observed and expected heterozygosities were calculated considering the clusters as independent populations. Within the $S$. macrocephala groups we found that group $\mathrm{C}$ had the highest level of genetic diversity, whereas group D was the most homogeneous, with a low rate of heterozygosity. For $S$. capitata, the results showed no differences among groups. Such homogeneity was not unexpected because most of the accessions of the $S$. capitata collection were sampled in two locations only. When calculating the Nei's $\mathrm{G}_{\mathrm{ST}}$ value among the groups formed by the STRUCTURE analysis approach, the $S$. macrocephala values were similar to other studies on species belonging to the Fabaceae family (Hamrick and Godt, 1996). In the $S$. capitata groups, the $\mathrm{G}_{\mathrm{ST}}$ values were lower than those found for other Stylosanthes species. AFLP studies estimated a $30 \%$ variation between $S$. humilis accessions from Mexico and South America (Vander Stappen et al., 2000), and another analysis on S. humilis H. B. K., based on AFLP, estimated $59 \%$ variation among groups. In contrast, the estimated variation among groups of $S$. viscosa (L.) Sw. was $66 \%$, which is a higher degree of genetic difference than that observed for either of the species in our study (Sawkins et al., 2001).

The sampling locations of the accessions of the $S$. macrocephala germplasm collection are listed in Table 1. The samples were collected in the Brazilian States of Bahia, Goiás, Minas Gerais, Piauí and the Distrito Federal, though information regarding the exact site of collection is lacking for several accessions.

Group A (Figure 1) consisted of accessions from Bahia and Goiás, and groups B and E included accessions from Bahia and Minas Gerais. Group C consisted mostly of accessions from Bahia, whereas group D included accessions from Bahia, Goiás, and the Distrito Federal. Barros et al. (2005) described 10 groups of $S$. macrocephala inferred from RAPD markers; $75 \%$ of all of the accessions were clustered into only one group, whereas seven of the remaining groups contained no more than two accessions. This clustering of $75 \%$ of the accessions into the same group limited the analysis of the genetic diversity and population structure in the $S$. macrocephala collection. Furthermore, 
the grouping created difficulties for comparing the RAPDderived clusters with those inferred from microsatellites. In this work, the Bayesian approach made it posssible to identify patterns of genetic variation among five $S$. macrocephala clusters and clarified the relationships among accessions within the same RAPD cluster previously described by Barros et al. (2005). Our results showed that the accessions collected in Bahia were distributed throughout all five of the groups obtained with STRUCTURE and that the group consisting mostly of accessions collected in this state exhibited the highest levels of genetic diversity. Based on these results, we hypothesize that the state of Bahia might be the location of the origin of $S$. macrocephala. However, data from natural populations are necessary to confirm this hypothesis.

The sampling locations of the accessions of the $S$. capitata germplasm collection are listed in Table 2. The plants were collected in several Brazilian states, along with the Distrito Federal, and samples were also obtained from Colombia and Venezuela. The Colombia accession (CPAC 1618 ) is a mixture of several Brazilian accessions developed by Instituto Colombiano Agropecuario (ICA) as "Capita" variety and is considered a reference to $S$. capitata. The Capita variety was used as standard to check the phenotypic characterization of the S. capitata germplasm. Notwithstanding, most of the accessions were collected in Goiás and Bahia (54 and 39, respectively), representing $49 \%$ of the total collection. Groups A, B and C contained higher numbers of Bahia and Goiás accessions, whereas group B contained more samples from Bahia than from Goiás. Group D also contained several Bahia and Goiás accessions, but the majority of the accessions were from Minas Gerais. The only accession from Colombia was allocated to group B. The eight accessions from Venezuela were distributed among groups A, B, C and D, with five accessions from Venezuela clustering in group $\mathrm{C}$, whereas each of the other groups contained only one accession each from this country. Group A comprised a great heterogeneity of localities, with accessions collected from all of the Brazilian states and South American countries, except for São Paulo and Colombia. Groups B and C contained the majority of the accessions from the northeastern states of Brazil and Goiás (central western region), whereas group D had more accessions from the southeastern states.

Due to sampling issues, many of the Brazilian states were poorly represented, and the genetic groups defined by STRUCTURE could not be correlated with geographic regions. Thus, for a more complete study of the genetic diversity of $S$. capitata in Brazil, new samples must be acquired, especially so from natural populations.

Using DARwin software, we constructed an NJ tree based on the Roger's genetic distances for $S$. macrocephala (Figure 1) and S. capitata (Figure 2). For S. macrocephala, groups $\mathrm{B}$ and $\mathrm{D}$, which contained the highest number of accessions assigned with more than $80 \%$ probability in the
STRUCTURE analysis, mostly remained clustered together in the tree. In contrast, other groups with more mixed individuals were randomly distributed along the $\mathrm{NJ}$ tree. Similar results were obtained for S. capitata, in which group A, with more mixed accessions, was also dispersed over the NJ tree. For the remaining groups, the majority of accessions clustered together in the $\mathrm{NJ}$ tree.

When directly compared, the results of the STRUCTURE and the NJ tree analyses revealed certain differences related to the number of groups and their genetic structure, but such differences are expected because these methods are based on distinct assumptions (Wang et al., 2009). Model-based approaches, such as STRUCTURE, are more efficient than distance-based methods in discriminating genetic groups, as cluster identification is not affected by the genetic distance or graphical representation chosen (Pritchard et al., 2000). Nevertheless, a combined analysis using different approaches may provide a better definition of the genetic diversity and structure in both of the Stylosanthes collections. Genetic diversity is the basis for genetic improvement, and consequently, knowledge about germplasm diversity has a significant impact on plant breeding (Huang et al., 2002).

Costa and Schultze-Kraft (1993) preformed a clustering analysis for $S$. capitata based on geographical regions and morpho-agronomic characteristics. As we used SSR markers obtained from genomic DNA, it is not possible to infer an association between the genetic markers and the phenotypic characters of the accessions. The groups obtained through molecular marker analysis are thus different from the ones obtained by Costa and Schultze-Kraft (1993), and both should be of importance to Stylosanthes breeders. In classical plant breeding programs, selection is done based on phenotypic evaluation, and improved progenies are obtained through crossing individuals of superior phenotypes and which, in general, are also genetically distant. Studies using molecular markers are complementary to phenotypic evaluation (Costa and Schultze-Kraft, 1993), and both are fundamental to genetic breeding programs.

Core collections were herein assembled for both Stylosanthes species, aiming to represent the entire genetic diversity identified in this study. The COREFINDER analysis showed that for S. macrocephala, $100 \%$ of the alleles found in this study could be represented by a core collection of 23 accessions. For $S$. capitata, only 13 accessions were necessary to represent $100 \%$ of the observed genetic diversity. Thus, we found that only a relatively small number of accessions were indeed necessary to represent the molecular diversity revealed in this study.

Certain factors may have contributed to the low number of accessions in the core collections suggested here. First, in terms of numbers of individuals collected in each region, the germplasm collection does not equally represent all of the distribution regions. As stated before, the germplasm collection includes some regions, such as the 
state of Goiás, with 54 different accessions, while others have only few representatives. We think this unequal representation may to some extent compromise the genetic diversity present in the collection and is likely reflected in the reduced number of individuals necessary to fully represent allelic diversity. In addition, S. capitata is an allotetraploid species that exhibits high levels of heterozygosity, which may contribute to reducing the size of the core collection (Cipriani et al., 2010). Sampling proportion and representation of base collection variation are the two most important characteristics to be observed when establishing a core collection (Hao et al., 2006). Brown et al. (1987) suggested that the number of accessions in the core should account for $5-10 \%$ of the base collection, representing at least $70 \%$ of its genetic diversity. Van Hintum (1999) recommended that the sampling proportion should vary between 5\% and 20\% of the base collection, depending on the main objective. Both of the core collections proposed here represent $100 \%$ of the molecular diversity found in this study, with the number of accessions accounting for $17 \%$ and $7 \%$ of the base collection for S. macrocephala and S. capitata, respectively.

Our results demonstrate the great potential of using molecular data to construct a core collection and thus improve the management and utilization of the Stylosanthes germplasm collection of Embrapa-Cerrados. Nevertheless, because we used a relatively small number of genomic markers for the genetic analysis, the data presented here should not be used alone when deciding on which accessions from the germplasm collection should be discarded or maintained. Additional molecular markers, including more SSRs and single nucleotide polymorphisms (SNPs), should be used to provide better coverage of the genome. This information should be coupled with phenotypic data for traits of interest, such as phenology and disease resistance traits, to make a final decision on the accessions to be maintained. To initiate this effort, more genotyping and phenotyping should be initiated with the core collection proposed here and expanded to other accessions as necessary. In addition, the core collection can also be used in the selection of parents for future crosses, based both on genetic distance and phenotypic traits of the accessions.

Another issue that requires consideration is the genetic purity of the accessions used in this work. It was previously shown by our group that $S$. capitata and $S$. guianensis can cross-pollinate (Santos-Garcia et al., 2010), but breeders have not accounted for cross-pollination during Stylosanthes seed multiplication. Here, we demonstrated a high level of heterozygosity in S. capitata in some undefined genetic groups obtained with STRUCTURE and the Neighbor-Joining based tree. These results might have been influenced by contaminations of the different accessions by seed multiplication plots established close to each other in the field.
In this work, we used polymorphic microsatellite markers to evaluate the genetic diversity of two Stylosanthes germplasm collections, and the results revealed a population structure among the accessions of both species. Our work indicates that even a small number of microsatellite markers is informative for genetic diversity studies in Stylosanthes species, providing a rapid and low-cost procedure for screening Stylosanthes germplasm collections. The results for $S$. macrocephala suggest some correlation between the region of collection and distribution among the groups based on the SSR markers. The same conclusion could not be reached for $S$. capitata because the collection does not equally represent the regions of distribution of this species in terms of quantity of accessions from each region, thereby indicating a need to improve sampling for this collection. The data from this study will certainly provide valuable information to geneticists and breeders for future improvement and conservation of Stylosanthes species.

\section{Acknowledgments}

The authors would like to thank Alexandre Franco Garcia for his assistance with the graphical representations and Fundação de Amparo à Pesquisa do Estado de São Paulo for financial support during the development of this project (Grant \# 2005/51010-0). Both MO Santos-Garcia and G Toledo-Silva received scholarships from FAPESP (2005/52211-9, 2010/50301-9). AP Souza is awarded a research fellowship from Conselho Nacional de Desenvolvimento Científico e Tecnológico (CNPq).

\section{References}

Barros AM, Faleiro FG, Karia CT, Shiratsuchi LS, Andrade RP and Lopes GK (2005) Variabilidade genética e ecológica de Stylosanthes macrocephala determinadas por RAPD e SIG. Pesq Agropec Bras 40:899-909.

Blair MW, Díaz LM, Buendía HF and Duque MC (2009) Genetic diversity, seed size associations and population structure of a core collection of common beans (Phaseolus vulgaris L.). Theor Appl Genet 119:955-972.

Brown AHD, Grace JP and Speer SS (1987) Designation of a "core" collection of perennial Glycine. Soybean Genet Newslett 14:59-70.

Chang-Shun J, Hu-Sen J, Xin-Rong M, Dong-Mei Z and YiZheng Z (2004) AFLP analysis of genetic variability among Stylosanthes guianensis acessions resistant and susceptible to stylo anthracnose. Acta Bot Sinica 46:480-488.

Chakraborty S (2004) High-Yielding Anthracnose-Resistant Stylosanthes for Agricultural Systems. ACIAR Monograph No. 111, Canberra, 268 pp.

Cipriani G, Spadotto A, Jurman I, Gaspero G, Crespan M, Meneghetti S, Frare E, Vignani R, Cresti M, Morgante M, et al. (2010) The SSR-based molecular profile of 1005 grapevine (Vitis vinifera L.) accessions uncovers new synonymy and parentages and reveals a large admixture amongst varieties of different geographic origin. Theor Appl Genet 121:1569-1585. 
Costa NM and Ferreira MB (1984) Some Brazilian species of Stylosanthes. In: Stace HM and Edye L (eds) The Biology and Agronomy of Stylosanthes. Academic Press, Sydney, pp 23-48.

Costa NM and Schultze-Kraft R (1993) Biogeografia de Stylosanthes capitata Vog. Y Stylosanthes guianensis SW. var. pauciflora. Pasturas Tropicales 15:10-15.

Creste S, Tulmann Neto A and Figueira A (2001) Detection of single sequence repeat polymorphisms in denaturing polyacrylamide sequencing gels by silver staining. Plant Mol Biol Rep 19:299-306.

Ebana K, Kojima Y, Fukuoka S, Nagamine T and Kawase M (2008) Development of mini core collection of Japanese rice landrace. Breeding Sci 58:281-291.

Edye L and Cameron D (1984) Prospects for Stylosanthes improvement and utilization. In: Stace HM and Edye L (eds) The Biology and Agronomy of Stylosanthes. Academic Press, Sydney, pp 571-588.

Evanno G, Regnaut S and Goudet J (2005) Detecting the number of clusters of individuals using the software STRUCTURE: A simulation study. Mol Ecol 14:2611-20.

Faleiro FG, Faleiro ASG, Cordeiro MCR and Karia TK (2003) DNA extraction methodology from leaves of native central Brazilian region species to operate molecular analysis. Bol Téc Embrapa Cerrados 92:1-5.

Ferreira M and Costa N (1979) Stylosanthes Sw. Genus in Brazil. EPAMIG, Belo Horizonte, 107 pp.

Hamrick J and Godt M (1996) Effects of life history traits on genetic diversity in plant species. Phil Trans R Soc B 351:1291-1298.

Hao CY, Zhang XY, Wang LF, Dong YS, Shang XW and Jia JZ (2006) Genetic diversity and core collection evaluations in common wheat germplasm from the Northwestern Spring Wheat Region in China. Mol Breed 17:69-77.

Huang XQ, Börner A, Röder MS and Ganal MW (2002) Assessing genetic diversity of wheat (Triticum aestivum L.) germplasm using microsatellite markers. Theor Appl Genet 105:699-707.

Kazan K, Manners JM and Cameron DF (1993) Genetic relationships and variation in the Stylosanthes guianensis species complex assessed by random amplified polymorphic DNA. Genome 36:43-49.

Kumar S and Sane PV (2003) Legumes of South Asia. Royal Botanic Gardens, Kew, 536 pp.

Laborda PR, Oliveira KM, Garcia AA, Paterniani ME and Souza AP (2005) Tropical maize germplasm: What can we say about its genetic diversity in the light of molecular markers? Theor Appl Genet 111:1288-1299.

Landjeva S, Korzun V and Ganeva G (2006) Evaluation of genetic diversity among Bulgarian Winter Wheat (Triticum aestivum L.) varieties during the period 1925-2003 using microsatellites. Genet Resourc Crop Evol 53:1605-1614.

Mannetje L't (1984) Considerations on the taxonomy of the genus Stylosanthes. In: Stace HM and Edye L (eds) The Biology and Agronomy of Stylosanthes. Academic Press, Sydney, pp $1-22$.

Powell W, Morgante M, Andre C, Hanafey M, Vogel J, Tingey S and Rafalski A (1996) The comparison of RFLP, RAPD, AFLP and SSR (microsatellite) markers for germplasm analysis. Mol Breed 2:1572-9788.
Pritchard JK, Stephens M and Donnelly P (2000) Inference of population structure using multilocus genotype data. Genetics 155:945-959.

Santos MO, Sassaki RP, Ferreira THS, Resende RMS, Chiari L, Karia CT, Faleiro FG, Jungmann L, Zucchi MI and Souza AP (2009a) Polymorphic microsatellite loci for Stylosanthes macrocephala Ferr. et Costa, a tropical forage legume. Conserv Genet Resourc 1:481-485.

Santos MO, Sassaki RP, Chiari L, Resende RMS and Souza AP (2009b) Isolation and characterization of microsatellite loci in tropical forage Stylosanthes capitata Vogel. Mol Ecol Resourc 9:192-194.

Santos MO, Karia CT, Resende RM, Chiari L, Jungmann L, Zucchi MI and Souza AP (2009c) Isolation and characterization of microsatellite loci in the tropical forage legume Stylosanthes guianensis (Aubl.) Sw. Conserv Genet Resourc 1:43-46.

Santos-Garcia MO, Resende RMS, Chiari L, Zucchi MI and Souza AP (2010) Mating systems in tropical forages: Stylosanthes capitata Vog. and Stylosanthes guianensis (Aubl.) Sw. Euphytica 178:185-193.

Santos-Garcia MO, Karia CT, Resende RMS, Chiari L, Vieira MLC, Zucchi MI and Souza AP (2012) Identification of Stylosanthes guianensis varieties using molecular genetic analysis. AoB Plants 2012:pls001.

Sawkins MC, Maass BL, Pengelly C, Newburry HJ, Ford-Lloyd BV, Maxted N and Smith R (2001) Geographical patterns of genetic variation in two species of Stylosanthes Sw. using amplified fragment lenght polymorphism. Mol Ecol 11:1947-1958.

Stace HM and Cameron D (1984) Cytogenetics and the evolution of Stylosanthes. In: Stace HM and Edye L (eds) The Biology and Agronomy of Stylosanthes. Academic Press, Sydney, pp 49-72.

Sun G, Díaz O, Salomon B and Von Bothmer R (1999) Genetic diversity in Elymus caninus as revealed by isozyme, RAPD, and microsatellite markers. Genome 42:420-431.

Van Hintum TJL (1999) The general methodology for creating a core collection. In: Johnson RC and Hodgkin T (eds) Core Collections for Today and Tomorrow. International Plant Genetic Resources Institute, Rome, pp 10-17.

Vander Stappen J, Weltjens I, Gama Lopez S and Volckaert G (2000) Genetic diversity in Mexican Stylosanthes humilis as revealed by AFLP, compared to the variability of $S$. humilis accessions of South American origin. Euphytica 113:145154.

Vander Stappen J, Gama Lopez S, Davila P and Volckaert G (2002) Molecular evidence for the hybrid origin of a new endemic species of Stylosanthes Sw. (Fabaceae) from the Mexican Yucatán Peninsula. Bot J Linn Soc 140:1-13.

Virk PS, Ford-Lloyd BV, Jackson MT and Newbury JN (1995) Use of RAPD for the study of diversity within plant germplasm collections. Heredity 74:170-179.

Wang L, Guan R, Zhangxiong L, Chang R and Qiu L (2006) Genetic diversity of Chinese cultivated soybean revealed by SSR markers. Crop Sci 46:1032-1038.

Wang ML, Zhu C, Barkley NA, Chen Z, Erpelding JE, Murray SC, Tuinstra MR, Tesso T, Pederson GA and Yu J (2009) Genetic diversity and population structure analysis of accessions in the US historic sweet sorghum collection. Theor Appl Genet 120:13-23. 
Westman AL and Kresovich S (1997) Use of molecular marker techniques for description of plant genetic variation. In: Callow JA, Ford-Lloyd BV and Newbury JH (eds) Biotechnology and Plant Genetic Resources: Conservation and Use. CAB International, Wallingford, pp 9-48.

Williams RJ, Reid R, Schultze-Kraft R, Costa NM and Thomas BD (1984) Natural distribution of Stylosanthes. In: Stace HM and Edye L (eds) The Biology and Agronomy of Stylosanthes. Academic Press, Sydney, pp 73-101.

Wright S (1978) Evolution and the Genetics of Populations, volume 4: Variability within and Among Natural Populations. University of Chicago Press, Chicago, $590 \mathrm{pp}$.

Zhang X, Blair MW and Wang S (2008) Genetic diversity of Chinese common bean (Phaseolus vulgaris L.) landraces assessed with simple sequence repeat markers. Theoretical and Applied Genetics 117:629-40.

Zong X, Redden RJ, Liu Q, Wang S, Guan J, Liu J, Xu Y, Liu X, Gu J, Yan L, et al. (2009) Analysis of a diverse global Pisum sp. collection and comparison to a Chinese local P. sativum collection with microsatellite markers. Theor Appl Genet 118:193-204.

\section{Internet Resources}

Goudet J (2001) FSTAT, ver. 1.2: a computer program to calculate F-statistics.

http://www2.unil.ch/popgen/softwares/fstat.htm (Mar 15, 2011).

Miller MP (1997) Tools for Population Genetic Analyses (TFPGA), ver. 1.3. A windows program for the analysis of allozyme and molecular population genetic data. Computer software distributed by author. http://www.marksgeneticsoftware.net

/_vti_bin/shtml.exe/tfpga.htm (Febr 22, 2011).

Perrier X and Jacquemoud-Collet JP (2006) DARwin software. http://www.darwin.cirad.fr/darwin (Mar 15, 2011)

Associate Editor: Everaldo Gonçalves de Barros

License information: This is an open-access article distributed under the terms of the Creative Commons Attribution License, which permits unrestricted use, distribution, and reproduction in any medium, provided the original work is properly cited. 